\author{
Faculty Research Working Papers Series
}

\title{
Who Should Shoulder the Burden? Global Climate Change and Common Ownership of the Earth
}

\author{
Mathias Risse \\ John F. Kennedy School of Government - Harvard University
}

December 2008

RWP08-075

The views expressed in the HKS Faculty Research Working Paper Series are those of the author(s) and do not necessarily reflect those of the John F. Kennedy School of Government or of Harvard University. Faculty Research Working Papers have not undergone formal review and approval. Such papers are included in this series to elicit feedback and to encourage debate on important public policy challenges. Copyright belongs to the author(s). Papers may be downloaded for personal use only. 


\title{
Who Should Shoulder the Burden? Global Climate Change and Common Ownership of the Earth
}

\author{
Mathias Risse \\ John F. Kennedy School of Government, Harvard University
}

November 29, 2008

\begin{abstract}
A common and intuitively plausible approach to thinking about the distributional questions that arise about global climate change is that the atmosphere is a "global sink" whose use is subject to regulation in terms of an equal-per-capita principle: Each person should have the same entitlement to pollute. This view, however, is plausible only if one thinks the earth as a whole belongs in some sense to humanity as such. This essay develops that standpoint of collective ownership of the earth and applies it to the aforementioned distributional questions. In light of that standpoint some of the ethical dimensions of global climate change take on a particular shape. It turns out, however, that the philosophically most plausible understanding of collective ownership of the earth does not support an equal-per-capita principle, not does it support certain versions of a principle of accountability for past emissions. Instead, we end up with a combination of "polluter pays" and "ability to pay" principles to the regulation of access to the absorptive capacity of the atmosphere into whose precise formulation certain aspects of historical accountability will, however, also enter.
\end{abstract}

1. An intuitively plausible view on distributional questions that arise in the context of climate change is that the atmosphere is a "global sink" whose use is subject to common regulation based on an equal per-capita principle (see e.g., Singer (2002)): Each person should have the same entitlement to pollute. If countries wish to pollute more than their aggregate share, they should purchase entitlements from others. This approach presumably derives what plausibility it has from the idea that original resources and spaces of the earth as a whole belong in some sense to humanity collectively, resources and spaces we need for survival but whose existence is nobody's accomplishment. In this regard, nothing should be true of the atmosphere that is not also true of other resources and spaces of the earth. 


\section{Climate change lends itself to a discussion in terms of collective ownership of the}

earth. Changes in weather patterns occur at the global level, and so affect the very object

that humanity arguably owns. Moreover, to the extent that human contributions to climate

change constitute a rights violation, it presumably is because the atmosphere has an

ownership status that is incompatible with greenhouse gas increases beyond a certain

level. Unless we are consequentialists, we cannot simply assume that the harm done

through climate change is a wrong. Competition harms people by thwarting their

interests, but this does not show any wrong was done. The ownership standpoint helps us

understand what wrongs occur in this case. Yet since there has been little interest in that

standpoint, there has been no systematic development of its implications regarding

climate change. ${ }^{1}$

\footnotetext{
${ }^{1}$ That humanity collectively owns the earth was a predominant idea in $17^{\text {th }}$ century political philosophy: Grotius, Hobbes, Pufendorf, Locke, and others debated how to capture this status and the conditions under which parts of the Global Common can be privatized. (See Buckle (1991) and Tuck (1999) for these discussions.) An exception to the general recent lack of interest in the standpoint of collective ownership is the literature on left-libertarianism (see e.g., Vallentyne and Steiner (2000a) and (2000b)). The ownership approach, in some way or another, is taken up, in the context of discussions about climate change, in Singer (2002), Hurka (1993), Grubb et al (1992), Grubb (1995), Traxler (2002), and Gardiner (2004). Gardiner (2004) distinguishes between "the historical principle" and "the common sink principle," the former capturing the idea that those who have polluted in the past should be responsible for bearing the costs of mitigating or adapting to climate change, and the latter being the idea that the atmosphere is collectively owned by humanity. He goes on: (p 580):”It is worth observing two facts about these two approaches. First, they are distinct. On the one hand, the historical principle requires compensation for damage inflicted by one party on another and does not presume that there is a common resource; on the other, the sink consideration crucially relies on the presence of a common resource and does not presume that any (further) damage is caused to the disenfranchised beyond their being deprived of an opportunity for use. Second, they are compatible. One could maintain that a party deprived of its share of a common resource ought to be compensated both for that and for the fact that material harm has been inflicted upon it as a direct result of the deprivation." But one wonders why there would be an independent ground to complain about harm that arises from pollution if the atmosphere is not owned in common anyway (a point also made by Hurka (1993)). The fact of interests being thwarted is not sufficient to generate a legitimate complaint. That is, if indeed the atmosphere is for everybody to pollute as they please, there is no independent complaint about the harm thus caused. The ownership standpoint also helps with other questions in this context. For instance, Sands (2003), p 14, states: "While it is clear that under international law each state may have environmental obligations to its citizens and to other states which may be harmed by its activities, it is less clear whether such an obligation is owed to the international community as a whole." The ownership standpoint cannot answer any legal questions, but it does make clear why in a moral sense there are such obligations to the international community.
} 
Yet if what is collectively owned is the earth as a whole, rather than the atmosphere in particular, we must assess carefully what this status implies for the use of the atmosphere. Libertarians have tried to reduce the idea of collective ownership ad absurdum by claiming that this view entails that humanity as such owns every nugget of gold found on the ocean floor and every drop of oil extracted on the Arab peninsula. ${ }^{2}$ Yet on a plausible understanding of what it is for humanity to own the earth, there are no such implications. But nor, then, does humanity collectively own the atmosphere in virtue of the fact that it collectively owns the earth. More thought is required to spell out what it means for ownership of the atmosphere (and for distributional questions) that humanity collectively owns the earth. Exploring these subjects is our goal here.

Climate change has become a common topic of discussion. Naturally occurring greenhouse gases, such as water vapor, carbon dioxide, and methane, form a thermal blanket that traps the sun’s energy inside the atmosphere of the earth and thereby makes our planet inhabitable. Over the last centuries, human activities have greatly increased greenhouse gas concentrations. Considerable quantities of carbon dioxide have resulted from burning fossil fuels (coal, oil, gas, which generate most of the world's energy), as well as from deforestation. Increasing evaporation of water amplifies the warming effects of these gases by causing a larger greenhouse effect than combustion and deforestation alone. Since climate impacts are self-magnifying in this way, small impacts can have severe consequences. The result is global climate change.

Greenhouse gases disperse uniformly in the atmosphere: what damage they cause does not depend on where they were emitted. On average, global surface temperatures

\footnotetext{
${ }^{2}$ We will revisit this point below.
} 
have risen by about 1.25 degrees Fahrenheit over the past 150 years. Most of the increase has occurred since 1970. Other actual or likely consequences of increasing greenhouse gas concentrations include changes in patterns of precipitation; thawing of permafrost; melting of glaciers and arctic summer ice; increases in sea levels; and changes in storm frequency and intensity. Depending on the location, the risks for human beings caused by climate change include decreases in the availability of water and in the productivity of farms, forests, and fisheries; a prevalence of oppressive heat and humidity; an increase in range and frequency of diseases and pests; damage from storms, floods, droughts, and wildfires, including increasing desertification; as well as losses resulting from sea-level rises (to which small islands and low-lying countries are most vulnerable), and decreases in biodiversity. The more these impacts materialize, the more they affect human living arrangements, which are adjusted to particular climatic conditions. While these changes will not be uniformly bad, the speed at which they occur is likely to be troublesome even for regions where these changes might otherwise be perceived as improvements. The Intergovernmental Panel on Climate Change has concluded that most of the increase in global averaged temperatures since the mid-twentieth century is likely due to the increase in man-made greenhouse gas concentrations. ${ }^{3}$

There are three ways of responding to this problem: to let these changes happen and suffer the consequences; to mitigate climate change (i.e., take measures to reduce its

\footnotetext{
${ }^{3}$ Established in 1988 by the World Meteorological Organization and the United Nations Environment Programme, the Intergovernmental Panel on Climate Change (IPCC) is a scientific body charged with assessing the risks of climate change caused by human activities. The IPCC's main activity is the publication of reports, which are widely cited in debates about climate change. For the background about climate change given above, see IPCC (2007a-c). The reports of this panel are the canonical source for the current state of climate science. Gardiner (2004) is an excellent survey of the scientific, economic, and philosophical questions about climate change as of 2004. Aldy and Stavins (2006b) contains a good summary of the scientific state of the art as of 2007, as well as a survey of possible policy responses.
} 
pace and magnitude); or to adapt (i.e., take measures to reduce adverse impacts on human well-being). Possibilities for mitigation include the reduction of greenhouse gases (through changing patterns of energy use, reforming agricultural practices, or limiting deforestation), as well as conceivably also large-scale geo-engineering to remove greenhouse gases from the atmosphere or to create cooling effects to offset greenhouse heating. Possibilities for adaptation include developing crops resistant to climate change; improving public-health defenses against hardships arising from climate change; projects of flood control and drought management; building dikes and storm-surge barriers against sea-level rises; and avoiding further development in areas that are at risk. ${ }^{4}$ The task of finding a global policy architecture that addresses climate change and that is economically plausible and politically feasible in the present, as well as potentially enduring (or adaptable) over time, confronts political obstacles that "may be every bit as real as the various natural constraints imposed by the laws of chemistry and physics" (Summers (2007), p xxiii).

Climate change also entails its share of philosophical problems, prominent among them - as we saw by taking a look at the "global sink" approach to the regulation of the use of the atmosphere -- the distribution of burdens that mitigation and adaptation entail. Who should make changes, and should there be international redistribution of the costs of these changes? In addition to the economic and political feasibility of the different climate change responses, there is also the moral question of what would be a fair

\footnotetext{
${ }^{4}$ The particular ways in which weather patterns change is not yet well understood, nor are the local effects of these changes. Scientific uncertainty exacerbates the task of assessing different response strategies. Also, mitigating climate change generates costs that must be born locally, by the present generation, and by countries in economically and technologically vastly different situations, but creates benefits that apply globally, to future generations, often to people who will be richer than their ancestors currently alive.
} 
distribution of the burdens that arise from adaptation and mitigation. To reformulate our goal in light of the sketch of the issues arising from climate change: This essay responds to the question of who should bear the costs of mitigation and adaptation by exploring what bearing the standpoint of humanity's collectively owning the earth has on it.

I begin by reacquainting readers with the standpoint of collective ownership by discussing a few themes from the work of Hugo Grotius. Grotius' ideas on the original ownership status of the earth will offer guidance throughout, especially his justly famous (and skeptical) ideas about the possibilities of owning the seas (the public goods problem of his day) which have an immediate bearing on the question of what entitlements there could be to the atmosphere. Like no other work in the philosophy of international relations, Grotius’ De Jure Belli ac Pacis Libri Tres (DJB), Three Books on the Law of War and Peace, published in 1625, makes ownership of the earth central to the relations among both individuals and political entities. His concern is with the "differences of those who do not acknowledge one common Civil Right whereby they may and ought to be decided” (I.1.I), differences he seeks to regulate non-parochially. By making collective ownership central, Grotius formulates a version of a standpoint of what one may call global public reason. Alas, Grotius' view is tied to the theological assumptions of his times, so we will need to update his views in a way that does not turn on these assumptions. The resulting view of collective ownership of the earth I call Common Ownership. Within Common Ownership we can explore different types of ownership status parts of the earth may have, and so generalize Grotius' reflections on the seas.

These reflections put us in a position to tackle our main task, to explore what Common Ownership implies about the ownership status of the atmosphere, that is, about 
what legitimate use can be made of it. Such an inquiry has to be the starting point for any response to the question of the distribution of burdens that arise from climate change, to the extent that such a response is available from within the ownership approach. One important result is that, in light of Common Ownership, it is a moral necessity at this stage to create fair norms of regulating access to the absorptive capacities of the earth. The standpoint of Common Ownership, that is, shows that distributive questions that arise about climate change form a moral problem of a particular character. This result contradicts in particular those who (such as apparently Posner and Sunstein (2007)) think that, as a normative matter (rather than as a matter of political reality), national selfinterest should carry considerable weight in assessments of future climate agreements.

Moreover, we find in a next step that neither the aforementioned equal per-capita approach nor a principle of accountability for historical emissions turn out to be acceptable -- at least none that finds fault with past emitters, before a certain stage, and none that endorses a form of strict liability that turns on neither blameworthy faults nor moral wrongs. Common Ownership rules out two prima facie plausible approaches to the distribution of burdens from mitigation and adaptation. This result might be surprising on both counts, and for rather different reasons. An equal-per-capita approach would strike many as the natural way of assigning burdens from climate change according to the standpoint of collective ownership, whereas the principle of historical accountability seems to have little to do with that standpoint in the first place. This leaves us with principles for regulating access to the earth's absorptive capacity that combine proposals in terms of who is best able to pay with proposals in term of current per-capita emissions. 
So we end up with a combination of "polluter pays" with "ability to pay" principles in whose formulation, however, our findings regarding the other principles will enter.

2. To introduce the standpoint of collective ownership, let me touch on a few themes from Grotius. Grotius offers this account of collective ownership of the earth: ${ }^{5}$

Almighty God at the creation, and again after the Deluge, gave to Mankind in general a Dominion over Things of this inferior World. All Things, as Justin has it, were at first common, and all the World had, as it were, but one Patrimony. From hence it was, that every Man converted what he would to his own Use, and consumed whatever was to be consumed; and such a Use of the Right common to all Men did at that time supply the Place of Property, for no Man could justly take from another, what he had thus first taken to himself; which is well illustrated by that Simile of Cicero, Tho' the Theatre is common for any Body that comes, yet the Place that every one sits in is properly his own. And this State of Things must have continued till now, had Men persisted in their primitive Simplicity, or lived together in perfect Friendship. (DJB, II.2.II.1)

God's gift can rightfully be put to use without any agreement. But this only works under primitive conditions, and does not even include a right to recover things left behind. Agreement is needed to create further-reaching rights, at least according to the account in De Jure Belli ac Pacis. Still, God's gift makes clear that the earth is for the use of human beings. As Buckle (1991) puts it, "in using the world for their own ends, human beings are not strangers (or trespassers) on a foreign soil. They are at home” (p 95).

Once primitive conditions have been left behind, property arrangements are conventional. To be adequate, these conventions must mind the fact that the earth was originally given to humankind collectively. One implication of this point is the postulation of a "right of necessity;" for

\footnotetext{
${ }^{5}$ I quote from DJB in the customary way, for instance “ II.2.II.1.” this means: Second volume; second book; second chapter; first section. The 2005 Liberty Fund edition is especially accessible. I also deal with Grotius' earlier work, Mare Liberum, Free Sea, which is part of a much larger work, De Jure Praedae Commentarius, Commentary on the Law of Prize and Booty, which, however, only became available in full in the $19^{\text {th }}$ century. For Mare Liberum, I quote the pages from the 2004 Liberty Fund edition.
} 
in a case of Absolute Necessity, that antient Right of using Things, as if they still remained common, must revive, and be in full Force: For in all Laws of human Institution, and consequently, in that of Property too, such cases seem to be excepted. (DJB, II.2.VI.2)

This right does not derive from charity (II.2.VI.4). Instead, it restricts private property rights as they could have been intended, or at any rate, their legitimate scope. After all, in addition to his account of the divine gift, Grotius also offer an account of natural rights that include "the Abstaining from that which is another's, and the Restitution of what we have of another's, or of the Profit we have made by it, the Obligation of fulfilling Promises, the Reparation of a Damage done through our own Default, and the Merit of Punishment among Men.” Society was formed for the protection of what is one's own, the suum (DJB, I.2.I.5), and a sphere of what is ours exists prior to actual property arrangements. Whereas Hobbes thought the most basic insight one could make uncontroversial was that everybody had a right to self-preservation, Grotius started with a number of laws of nature in which what individuals have a right to is spelled out in ways meant to be reasonable for everybody. Grotius is guided by solidaristic assumptions, and an understanding of humanity as susceptible to moral motivation in principle.

Some limitations to property are not rights of necessity but general restrictions of what may be claimed under any conditions. Others may avail themselves of innocent profits (e.g., sail on our rivers), or demand free passage (even when trading with third parties, II.2.XI-XIII), rights that if denied can be claimed by force (II.2.XIII.3). People may rest ashore to recover from a journey, even build “a little Cottage” (II.2.XV.2), and seek “a fixed Abode” (II.2.XVI.2) if prosecuted at home, assuming they abide by local laws. Products must be sold at reasonable prices if they are not needed by the producers (II.2.XIX). Even the right to marriage ought not to be denied, women apparently being 
part of the common stock (II.2.XXI). All these rights are owed to all, not just a selected few (II.2.XXII). These strong constraints on ownership are much at odds with our current practices. As a striking illustration, consider cases of forced immigration:

And if there be any waste or barren Land within our Dominions, that also is to be given to Strangers, at their Request, or may be lawfully possessed by them, because whatever remains uncultivated, is not to be esteemed Property, only so far as concerns Jurisdiction, which always continues the Right of the antient People. (II.2.XVII).

We will elaborate on this theme below, when discussing Grotius' account of the ownership of the seas, but what these cases make clear already is that the collective ownership status of earth, in conjunction with the additional natural rights Grotius postulates, puts considerable limitations on the possibility of privatization.

3. While Grotius took the biblical standpoint of the earth as a divine gift, like Locke he held that this view should be acceptable even if humankind had never received any revelation. Indeed, the view that the earth originally belongs to humankind collectively is plausible without religious input. Philosophically, we have much to gain by revitalizing and developing the idea that humanity collectively owns the earth, since this status affects what people can do with portions of the planet. While reflections about personhood and how persons ought to relate to each other are foundational to moral theory, reflection about original ownership will be able to help along moral arguments by appealing to the fact that resources and spaces that we all need are nobody's accomplishment. Among other things, this standpoint generates constraints on what immigration policies to adopt (see Blake and Risse (2007), Blake and Risse (forthcoming)); it also leads to a conception 
of human rights (see Risse (2009a), (2009b)); and at this moment we are exploring how this standpoint bears on distributional questions in the context of global climate change.

Two points are indeed obvious enough: first, the resources of the earth are valuable and necessary for any human activities to unfold; and second, those resources have come into existence without human interference. These points must be considered when individual accomplishments are used to justify property rights strong enough to determine use across generations. ${ }^{6}$ Egalitarian Ownership is the view that the earth originally belongs to humankind collectively: all humans, no matter when and where they are born, must have some sort of symmetrical claim to it. ("Original" ownership does not connote with time but is a moral status.) This is the most plausible view of original ownership in light of the two points just made. Egalitarian Ownership is detached from the complex set of rights and duties civil law delineates under the heading of property law (Honore (1961)). At this level of abstraction from conventions and codes that themselves have to be assessed in relation to views on original ownership, all Egalitarian Ownership states is that all humans have a symmetrical claim to original resources.

One may say that the term "ownership" is misleading here, but I use it since there is this connection to the familiar, thicker notions of ownership in civil law; and we are, after all, concerned with what sorts of claims individuals have to resources. To be sure, the considerations motivating Egalitarian Ownership speak to raw materials only, not to what human beings have made of them. The distinction between what "is just there" and what has been shaped by humans is blurred, say, for land human beings have wrested

\footnotetext{
${ }^{6}$ Much has been written on foundations of property; see Becker (1977), Reeve (1986), or Ryan (1987).
} 
from the sea, or for natural gas harnessed from garbage deposits. But by and large, we understand well enough the idea of what exists without human interference. ${ }^{7}$

We must now assess different conceptions of Egalitarian Ownership. Such conceptions differ in how they understand the symmetry of claims individuals have to original resources. There are, roughly, four types of ownership-status an entity may have: no ownership; joint ownership -- ownership directed by collective preferences; common ownership - in which the entity belongs to several individuals, each equally entitled to using it within constraints; and private ownership. Common ownership is a right to use something that does not exclude others from also using it. If the Boston Common were held as common ownership when it was used for cattle, a constraint on each person's use could be to bring no more than a certain number of cattle, a condition motivated by respect for co-owners and the concern to avoid the Tragedy of the Commons. Yet if they held the Common in joint ownership, each individual use would be subject to a decision process to be concluded to the satisfaction of each co-owner. Joint ownership ascribes to each co-owner property rights as extensive as rights of private ownership, except that others hold the same rights: each co-owner must be satisfied on each form of use.

So there are various interpretations of Egalitarian Ownership: resources could be jointly owned, commonly owned, or each person could have private ownership of an

\footnotetext{
${ }^{7}$ A more difficult question is under what conditions man-made products, including improvements of original resources, should no longer be accompanied by special entitlements of those who made them or their offspring. See Blake and Risse (forthcoming) for discussion. Egalitarian Ownership formulates a standing demand on all groups that occupy parts of the earth to inhabit the earth in a manner that respects this symmetrical status of individuals with regard to resources. That Egalitarian Ownership operates in this way should be intelligible and acceptable even within cultures where individuals are not seen as property owners. Nothing about Egalitarian Ownership precludes such cultures from being acceptable to their members even if they do not treat individuals themselves as property holders. Yet even cultures that do not see individuals themselves as property holders must indeed be acceptable to those who live in them especially because all individuals have symmetrical claims to original resources.
} 
equal share of resources (or a value equivalent). These conceptions carve out a preinstitutional space of natural rights that constrain property conventions which in turn regulate what natural rights leave open. I submit that Common Ownership is the most plausible conception. ${ }^{8}$ While I cannot offer a complete argument for this proposal here, I offer elaboration on what common ownership means, what it entails, and why it should be preferred to the other conceptions as an interpretation of Egalitarian Ownership. ${ }^{9}$

The core idea of common ownership is that all co-owners ought to have an equal opportunity to satisfy their needs to the extent that this turns on obtaining collectively owned resources. This formulation, first, emphasizes an equality of status; second, it points out that this equality of status concerns opportunities to satisfy needs (whereas there is no sense in which each co-owner would be entitled to an equal share of what is collectively owned, let alone to the support of others in getting such a share, any more than any co-owners of the Boston Common had a claim to such a share or to the support of others to obtain it); and third, it does so insofar as these needs can be satisfied with resources that are collectively owned (that is, nothing at all is said about anything to which the original intuitions motivating Egalitarian Ownership do not apply).

To put this in the Hohfeldian rights terminology, common ownership rights must minimally include liberty rights accompanied by what Hart (1982) calls a "protective

\footnotetext{
${ }^{8}$ In capital letters, “Joint Ownership” and “Common Ownership” are names of interpretations of Egalitarian Ownership and hence views about ownership of the earth, whereas in small letters "joint ownership" and "common ownership" are general forms of ownership of anything. I continue to say that humanity "collectively" owns the earth if the precise form of ownership does not matter.

${ }^{9}$ Risse (2005) offers supportive arguments, showing why other conceptions are problematic. I develop all of this at length in my forthcoming book on The Grounds of Justice. See also Risse (2009a)
} 
perimeter” of claim rights ( $\mathrm{p} 171) .{ }^{10}$ To have a liberty right is to be free of any duty to the contrary. Common ownership rights must include at least rights of that sort; that is, coowners are under no duty to refrain from using any resources. But the symmetry of claims postulated by Egalitarian Ownership demands more than liberty rights. In light of the intuitions supporting Egalitarian Ownership, to count as an interpretation of it, Common Ownership must guarantee minimal access to resources, that is, impose duties to refrain from interference with certain forms of use of resources. Therefore we must add that protective perimeter of claim rights to the liberty rights. We obtain enough mileage from the original intuitions to require that common ownership rights (for Common Ownership to serve as an interpretation of Egalitarian Ownership) be conceived of in sufficientarian terms, in the sense that no co-owner should interfere with actions of others if they serve to satisfy basic needs. These intuitions cannot be pressed beyond that. Equal Division and Joint Ownership both press them too far.

Yet we do have to add one more right. We must also make sure individuals can maintain their co-ownership status under more complex arrangements. A necessary condition for the acceptability of such arrangements is that the core purpose of the original rights can still be met. That core purpose is to make sure co-owners have the opportunity to meet their basic needs. In Hohfeldian terminology, co-owners have an immunity from living under political and economic arrangements that interfere with the ability of those subject to them having such opportunities.

Since a rejection of specifically Equal Division (as defended, e.g., by Steiner (1994)) matters to my argument later, let me discuss it a bit more. Equal Division gains

\footnotetext{
${ }^{10}$ For the Hohfeld terminology, see Jones (1994), chapter 1; Edmundson (2004), chapter 5; Wenar (2005).
} 
plausibility from the idea that there is a (figurative) heap of resources to which each human being has an equal claim. Yet the idea of "dividing up” such a heap presupposes an ability to assign values to sets of resources to render them comparable (for instance, through a market mechanism). But many materials only acquire value through activities that require social contexts in which not all humans participate equally. What makes resources valuable contradicts claims to symmetry with regard to the heap of resources after an application of the valuing operation. One may say what we collectively own is the overall value of resources, perhaps determined by market prices, and that it is that value of which each person should have an equal share. But again, individuals have no symmetrical claims to that overall value for the reason specified. Defenders of Equal Division face a dilemma: either they claim that what individuals have symmetrical claims to are the original resources themselves; if so, they have no way of saying what counts as an equal share. Or else they say that it is the overall value of these resources, however assessed, to which individuals have such claims. But in that case the claim is false.

One might object that it is not generally true that independent actions or accomplishments of others that raise the value of one's own assets should not count towards the value of those assets. If I own a field and others open a plant nearby, the value of my field may rise because now people have more reasons to live in our area. But none of this value increase would be owed to those others (in the sense that it must be transferred to them). It is irrelevant to my ownership claims if people's activities contribute differently to the value of any item that is priced. Similarly, one might say that I have a claim to an equal share of the earth's resources regardless of whether the valuing mechanism chosen to divide up the overall heap of resources has arisen through 
differential activities of different people. But such examples presuppose an ownership structure of the sort only the civil law can prescribe. My field already has a value that then changes in response to the actions of others. But the point of my argument against Equal Division is that no value can be assigned to original and hence still entirely unvalued resources in a way that does not break the original symmetry of claims.

4. One question that naturally arises on Grotius' account of collective ownership (mutatis mutandis for all such accounts) is whether all of the divine gift can be occupied at the exclusion of others. Grotius famously responds negatively, arguing that the seas could and should not be so occupied. His discussion is of interest to us because, after arguing that no one can have individual property claims on the sea, he claims: "The same might be alleged of the Air too, could we put it to any Use, without being posted on the Surface of the Earth" (DJB II. II. III. 1). Nowadays, alas, we can put "the Air" to use. So we will apply what we learn from Grotius' account of the seas to that scenario and then derive some lessons for distributional questions that arise in the context of climate change.

Grotius' work contains two accounts of private property, so two ways of generating the question of whether everything can be appropriated. According to De Jure Belli, the original common property is divided ever more, in response to changing socioeconomic arrangements (II.2.II.5). People realize that adjustments are necessary, make agreements to that effect, or accept them tacitly. First occupancy decides who gets to privatize what. ${ }^{11}$ At the beginning of DJB II.2.III, following his views about

\footnotetext{
${ }^{11}$ See DJB, II.2.II.5, but also II.3.1 and II.3.IV.1, and in II.8.VI.
} 
privatization, Grotius explains that the sea is excluded from privatization because it is big enough for everybody's use. This emphasis relates to his point in II.2.II, that the arrangement of common use served the same purpose as the subsequent introduction of private property. For the sea no new property regime was needed to ensure arrangements under different conditions serve the original purpose.

The earlier Mare Liberum (ML) also explains the process by which things became "proper.” Again we read that at the earliest stage there merely exists a right to use. But Mare Liberum does not turn on agreements to explain what happens next. Grotius distinguishes between two stages of private acquisition (ML, pp 22f). First, acts of use create special relationships between things and certain individuals. Sometimes use amounts to consumption, thus to abuse: the apple I eat is no longer left for others to use similarly. Other things are made worse by being used. A form of private ownership is then inseparable from use. At the second stage, Grotius explains that something similar also occurs in other cases. The passage speaks of "a certain reason" (the Latin word being "ratio"). The value of assigning objects to specific people is realized: the "ratio" was that occupation often changes objects of use. Instead of compacts modifying common use, private ownership arises through natural extensions of use.

Grotius next assesses the limitation of appropriation, especially regarding the seas (p 24). The centrality of occupation as basis for private ownership becomes clear again. ${ }^{12}$ One reason why Grotius rejects the idea that some people can lay claims to the seas here is that the seas cannot be occupied. The mechanism that explains which individual would

\footnotetext{
12 On the importance of occupation, see ML, p 24, p 34. On p 116 we read that, if things cannot remain common, they become the property of the first taker, both because the uncertainly of ownership could not otherwise be avoided, and also because it was equitable that a premium be put upon diligence.
} 
be the owner at the exclusion of others does not apply to the seas. Even if occupation were possible, it would be wickedness because the gains for occupiers would not depend on excluding others. There appears to be a tension between De Jure Belli and Mare Liberum, as one of them but not the other gives an important role to convention. Yet the point in both is that the earth belongs to everybody, but that it is left to the will of men to develop this gift. Precisely how particular arrangements come about is inessential, as long as the changes continue to make sense of the original situation of equity, and the changes are reasonable adjustments to new circumstances given Grotius' starting points. ${ }^{13}$

What is lasting about Grotius' arguments about the “free sea?” Nowadays, parts of the sea can be monitored and patrolled by air and by water, so differences between the ability to occupy land and water are a matter of degree. Nor does it continue to hold that use by one party leaves intact what others could do with areas of the sea: that much is true for ships traveling through, not for other uses, like fishing and seabed exploitation. Writing in the late $19^{\text {th }}$ century, Henry Sidgwick realized that Grotius' argument with regard to fisheries had expired (Sidgwick (2005), p 228). In light of these changes, on Grotius' own terms, complete freedom of the seas would no longer be called for.

The most durable of Grotius' ideas here is that, first, given a certain state of technology, the original purpose of natural ownership rights, in the case of the sea, can be preserved without new property arrangements; and that, second, this point entails that no such new property arrangements should be made, barring changes in technology. Behind this idea, in turn, we find a conservative principle of occupation at the exclusion of others: unless there is a good reason to exclude people from parts of the earth by

\footnotetext{
${ }^{13}$ See also Buckle (1991), p 43.
} 
occupation, they should not be so excluded. Collective ownership, although consistent with occupation at the exclusion of others under certain conditions, also imposes obstacles on the occupation of parts of the collectively owned planet. We should see these constraints in connection with other constraints on the formation of private property rights, and thus as aspects of an overall coherent development of the idea of collective ownership. The founding of communities presumably is a good reason to exclude people - Grotius takes no issue especially with the existence of states. But that particular reason, given the conditions under which Grotius wrote (and under which we still live), would have no bearing on the seas. The burden of proof, at any rate, is on those who wish to legitimize occupation, and as Grotius saw it (as we might now add, in light of the technological accomplishments of his age), that burden could not be met for the sea. ${ }^{14}$

5. Our non-theological account interprets Common Ownership in terms of a Hohfeldian liberty right, an elementary claim right, as well as an immunity right not to have to live under political and economic arrangements that would not preserve the purpose of these liberty and claim rights. On this approach too we must ask: does this view entail that each part of the commonly owned earth is subject to occupation at the exclusion of others? This question actually assumes a more general shape, given that we are exploring the connection between the ownership status of the earth and that of its parts. Generally, there are three manners in which parts of the earth can be owned, or three different ownership statuses parts of the earth could have, in light of Common Ownership. First, parts of the earth could be owned in accordance with conventions that allow for

\footnotetext{
${ }^{14}$ For the more recent development of the law of the seas, see Malanczuk (1997), chapter 12.
} 
occupation by some at the exclusion of others (in a manner that would still have to respect the original natural rights, and where then also other constraints would enter, such as constraints on immigration, see Blake and Risse (forthcoming) and Blake and Risse (2007)). Second, parts of the earth could remain in the original common ownership, without that original status being substituted with more specific conventions.

These two sorts of ownership status were present in Grotius as well, and only those two. Questions about ownership status reduce, then, to a choice between them: for instance, the seas either could be appropriated by some at the exclusion of others, or else had to be left in common ownership. There is, however, a third, intermediate ownership status. Conceivably, parts of the earth can be owned in such a way that common ownership gives way to specific property conventions, but not conventions that provide for occupation by some at the exclusion of others. These conventions might come with different regulations for different public goods generated by the same area. For instance, as far as the seas are concerned, the ability of ships to travel through may remain unregulated, while fisheries and exploitation of seabed resources may not. For each such case we would have to ascertain what the relevant considerations are and how to apply them. Given Common Ownership, our more general question becomes: under what conditions do these different manners of owning parts of the earth respectively apply?

In light of the political and economic concerns and technological possibilities of his age, Grotius was interested primarily in the seas, but regions that do not straightforwardly lend themselves to being governed by property conventions that allow for appropriation by some at the exclusion of others also include "the skies," that is, the air space above the land and the seas, or the atmosphere, as well as Antarctica and outer 
space. In Grotius' day, all those areas were largely untouched by human activities. No question arose about the justifiability of privatization in these areas, although we saw above that Grotius also acknowledges an application of his ideas to "the Air." Yet after technological changes have triggered human interest in these regions, each has become the subject of a sophisticated body of international law. The term "common heritage of mankind” has been applied to all these areas. ${ }^{15}$

Within our non-theological approach, we can regain Grotius' conservative principle of occupation at the exclusion of others, and apply it to these areas. Under Common Ownership, the presumption is that parts of the earth can indeed be used by some at the exclusion of others. Yet it takes a good reason to claim regions in such a way. One such reason (here too) is the founding of communities that would not be viable if they could not exclude non-members. Collective ownership generates constraints that make communities acceptable to both members and non-members (considerations regarding immigration, or human rights). Within communities, additional considerations determine what property arrangements are acceptable to members. (For instance, the existence of coercive and cooperative structures matters for questions of distributive justice within states.) The ownership status of the earth puts the burden of proof for the acceptability of appropriation at the exclusion of others on those who wish to do so.

Sometimes there are strong reasons not to subject parts of the earth to appropriation at the exclusion of others, and thus this burden of proof cannot be met. To continue with the formulation of that point (now at the more general level, no longer tied to the seas), let me introduce some helpful vocabulary. Capturing distinctions common in

\footnotetext{
15 See Buck (1998) for the background to that term; also Attfield (2003), pp 169-172.
} 
the public goods literature, Buck (1998), chapter 1, for instance distinguishes among different categories of goods, depending on two criteria: excludability and subtractability. That is, goods may allow more or less readily for the exclusion of people from their use; moreover, use by some individuals prevents similar use by others to more or less considerable degrees. ${ }^{16}$ Combining this terminology with the earlier considerations regarding communities, a clear case for leaving an area in common ownership is if: first, the area does not lend itself to the founding of durable communities (where the paradigmatic case of such a scenario is that general conditions of human species functioning do not allow for such a founding); and second, the area is also characterized by low degrees of excludability and subtractability. For such areas, nobody could sensibly be expected to respect any proposed new property convention.

At some stage, these conditions were satisfied for each area in the common heritage, trivially so when lack of technology rendered their use impossible. Yet technological progress has rendered each of these areas interesting for human purposes. These areas still do not lend themselves to the founding of lasting communities, ${ }^{17}$ but

\footnotetext{
${ }^{16}$ We can combine these criteria in four different ways, which, according to Buck, render particular property arrangements appropriate (and especially for parts of the earth, the goods in which we are currently interested): If there is little difficulty in excluding others, and use subtracts from the value of the goods, a private property regime suggests itself. If there is little difficulty in excluding others, but use by others does not subtract from the value of the goods, a toll regime suggests itself. If there are difficulties in excluding people, and use subtracts from the value of the goods for each user, a common pool regime suggest itself. And if there are difficulties in excluding others and use does not diminish the value of the goods for each user, these goods should be kept as public goods. These distinctions map onto the threefold distinction among ownership statuses I introduced above: the private property regime corresponds to the ownership status that allows for appropriation at the exclusion of others; the public goods regime to the ownership status that denies the appropriateness of property conventions that go beyond the original common ownership rights; and the toll regime and common pool regime to the ownership status that allows for conventions that go beyond the original ownership rights without being focused on occupation at the exclusion of others. For discussion of public goods and common pool regimes from an institutional perspective, see also Ostrom (1990) and Bromley (1992).

${ }^{17}$ There are space stations, research stations in Antarctica, submarines, and planes, but none of these should count as serious counterexamples to the claim just made.
} 
exclusion has become easier, and new ways of exploiting goods create a higher degree of subtractability than before. The changes apply differently to the four areas, and took effect first with regard to the seas, prompting Grotius to write Mare Liberum. ${ }^{18}$ If such deviations occur from what above I called the clear case for leaving areas in common ownership, we must revisit what Common Ownership entails for the respective areas.

Crucially, what the original common ownership rights imply for such areas depends on the state of technology, and might change over time: Technological change might bring about a situation where the reasons why certain areas should remain in common ownership lapse. Under the new conditions, appropriation at the exclusion of others might be acceptable. More plausibly, there might then be a need for property conventions that replace the original common ownership rights without allowing for appropriation at the exclusion of others. Such conventions will be appropriate whenever neither the clear case for leaving areas in the original common ownership, nor conditions for the founding of lasting human communities apply.

6. Let us turn to the atmosphere. The skies are a paradigmatic case of a part of the collectively owned earth that should neither be left in the original common ownership, nor be subject to private appropriation. Moreover, different conventions should be adopted for different public goods provided by the skies. ${ }^{19}$ Before the invention of airplanes, the skies did not play much of a role in human activities. Yet this invention

\footnotetext{
${ }^{18}$ Buck's (1998) discussions about Antarctica, the open seas, the atmosphere, and outer space make clear how complex the legal history of all this is.

${ }^{19}$ As Sands (2003), p 13, explains, according to the legal understanding of these terms, airspace above land ends at the point at which the legal regime of outer space begins.
} 
created a new good that had to be allocated: control of airspace. Since the invention of planes led to the invention of aerial bombing, such control is a precious good indeed. Control of airspace is highly subtractable, and technological advancements increased possibilities for exclusion. The norm quickly emerged that control of the airspace above any country should belong to that country. This convention is supported by whatever arguments support the existence of states in the first place: Since aerial control potentially threatens the security of states, it is appropriate for states to claim such control..$^{20}$

A good that was not created by technological advances, but that only became perceived as a good through such advances is the absorptive capacity of the atmosphere, that is, the capacity of the atmosphere to absorb greenhouse gases in a manner that leaves the basic climate conditions of the earth unaffected. Like airspace control, the absorptive capacity of the earth is a good of (potentially very) high subtractability: there are limits to how much greenhouse gas there can be in the atmosphere without its presence triggering major climate changes. Unlike airspace, it is a good of low excludability: what quantity of greenhouse gases is emitted depends on what happens in individual states, but emissions disperse throughout the atmosphere and cannot be prevented from doing so by known technologies. Unregulated emission of greenhouse gases has created a potentially very dangerous situation, which, in particular, would make it impossible for individuals to exercise their natural ownership rights. According to the ownership approach, then, there is now a great moral urgency to regulating access to the absorptive capacity of the earth, with the goal of making sure individuals can continue to exercise their natural rights. This result objects to those who (such as apparently Posner and Sunstein (2007))

\footnotetext{
${ }^{20}$ See Buck (1998), chapter 5.
} 
think that, as a normative matter (rather than as a matter of political reality), national selfinterest should carry considerable weight in assessments of future climate agreements.

How, then, should we regulate the absorptive capacity of the earth? What principle(s) should determine who gets how much access to it? ${ }^{21}$ This question takes us to theories of fair division. Such theories deal with the arbitration of competing claims, which may not always literally “divide” anything, but may for instance regulate access. Theories of fair division provide resources to reach decisions under circumstances of persistent disagreement that allow for claims to be accommodated proportionately. A major difficulty is that there is often a lack of salience for any particular solution under the typical circumstances that call for fair-division solutions in the first place, namely conditions of persistent disagreement. ${ }^{22}$ Nevertheless, the ownership approach helps us reject two common approaches to the question of how to regulate access to the absorptive capacity of the earth. The first approach we will reject is the idea that each person has a claim to an equal per-capita share of the atmosphere, and the second is a principle of accountability for historical emissions -- at least those versions of it that finds fault with

\footnotetext{
${ }^{21}$ Shue (2001), p 450, thinks it is "slightly odd" to treat the absorptive capacity as a vital resource, but then goes ahead and does it, because it is, as he says, a necessity, and an increasingly scarce one. Buck (1998), pp 125-128 is reluctant to talk about a common pool regime in the case of the atmosphere (a property regime she thinks should apply for goods of low excludability but high subtractability). Her point is that atmospheric resources are not analogous to resources in other domains (such as fisheries or seabed resources), and that therefore this terminology does not apply. Clean air, for instance, does not lend itself to ideas of "resource flow" in the same way in which other resources do. Instead, we should think about the atmosphere in terms of a protective regulatory regime charged with the regulation of externalities. But these considerations should not beproblematic for our discussion here. Within the literature that Buck (1998) is part of, a common pool regime has a rather specific meaning, and thus its applicability to the atmosphere might not be straightforward or even sensible. Similar problems might arise with regard to the absorptive capacity of the earth (which is not a term Buck uses), but nevertheless, within the approach we have adopted, we can still say everything we want to say about the absorptive capacity of the earth and its regulation.

${ }^{22}$ For more on the difficulties involved in applying fair division (by way of contrast with aggregation methods), see Risse (2004). For introductions to theories of fair division, see Young (1995) and Brams and Taylor (1996).
} 
past emitters, before a certain stage, or that endorse no-fault-based strict liability. Once we have rejected those two proposals, we can state a proposal for the division of burdens arising from climate change. Given that a major difficulty in fair-division theories indeed is that there might well be a lack of salience for any particular solution under the typical circumstances that call for fair-division solutions in the first place, the plausibility of one proposal often directly gains from weaknesses of other proposals. For that reason, the plausibility of that final proposal will benefit much from the rejection of those two other

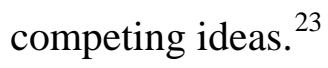

Let us begin with the per-capita approach. As we saw, Singer (2002) and others have asserted that humanity collectively owns the absorptive capacity of the earth. From there Singer derives a per-capita approach as the principle of distribution that pertains to this collectively owned entity. Each person should be allowed to use up the absorptive capacity of the earth to the same degree, and thus possess the same entitlement to pollute. One could implement such an approach via a "cap-and-trade” system. A global limit on greenhouse gas emissions would be chosen, and each country obtain an amount of permissible emissions (its "cap”) based on population size. A country that wishes to generate more pollution has to purchase additional rights.

One way of assigning these caps is to argue that each person, say, since the beginning of the industrial revolution has the same entitlement to pollute, and determine

\footnotetext{
${ }^{23}$ Grubb et al. (1992) discuss various ways in which the burden of global warming can be split. They also mention various ways of thinking about how to allocate emissions to countries, but area, GDP, population, etc. But their goal is to come up with a politically realistic solution, and none of these methods meets that test. (See also Grubb (1995)) Traxler (2002) also discusses several ways of dividing the burdens of climate change, and, mostly for practical reasons, settles for a principle of equal burdensomeness. Neumayer (2000), p 187, states: "That emission rights should be allocated on an equal per-capita basis and that historical differences in emissions should also be accounted for is (...) the shared view of almost every scholar and policy maker from the developing world.”
} 
what amount of pollution that would be in light of the maximally bearable atmospheric concentration of greenhouse gases. Another approach is to think of the distribution in terms of current populations. Variations are conceivable: one could index the relevant population sizes to a year before which public actors could have been reasonably expected to design environmental policies to combat pollution. Or one could do indexing to a future year, to avoid perverse incentives for population policy or to accommodate countries with young populations. ${ }^{24}$

The equal per-capita approach is appealing because it allows us to regulate access to the absorptive capacity in a manner that does not depend on existing political structures. This approach draws its prima facie plausibility from the view that, between any two people, neither has done more than the other to create the absorptive capacity of the earth. Alas, at this stage, we have two responses to this appeal to the ex-ante symmetry of individuals with regard to the atmosphere. First, we have rejected the EqualDivision conception of Egalitarian Ownership, which understands the original collective ownership status of earth as entailing, for each person, a claim to an equal share of resources. According to Common Ownership, no such claims arise in the first place. Second, assuming the idea that humanity collectively owns the atmosphere will be plausible only to those who also endorse collective ownership of the earth, ${ }^{25}$ the argument in Singer (2002) is the sort of move that right-libertarians have (erroneously) employed to lead the collective ownership approach ad absurdum. Can somebody

\footnotetext{
${ }^{24}$ Grubb et al. (1992) make clear that the per-capita allocation approach may take a contemporary or historical form, depending on who is counted. Singer (2002) too discusses both possibilities.

${ }^{25}$ This seems straightforward enough. There is nothing distinct about the atmosphere in a way that would justify restricting the domain of collective ownership in this way.
} 
seriously claim, asks for instance Murray Rothbard, that a newborn Pakistani baby has a claim to a plot in Iowa that Smith just transformed into a field? ${ }^{26}$ As soon as one ponders such implications of collective ownership, says he, one realizes its implausibility. Yet no sensible conception of Egalitarian Ownership endorses the idea that collective ownership of the earth implies such ownership of any particular object on, or part of, the earth. This inference especially does not hold for the absorptive capacity of the earth, or the "global sink.” It is because this inference fails that we had to discuss the ownership status of parts of the earth the way we did above. ${ }^{27}$ The idea that any two people are symmetrically located with regard to the atmosphere does not lead to the equal per-capita approach.

However, we have by now also seen how to approach the question of the ownership status of the atmosphere from the standpoint of Common Ownership. By way of contrast with the ex ante argument just considered, one may think of the equal percapita approach as the ex post solution to the problem of how to regulate access to the absorptive capacity of the earth in accordance with Common Ownership. But this argument fails. Note some implications of the equal-per-capita approach. Countries would obtain emission contingents regardless of how this affects their economy, how they use the contingents, what importance they have for people's lives, and whether countries take any measures to reduce emissions. A world-wide “cap-and-trade” system

\footnotetext{
${ }^{26}$ Rothbard (1996), p 35; Hospers (1971), p 65, makes a similar point.

27 Jamieson (2001) also advocates the equal per capita proposal, as does Baer (2002; see also Athanasiou and Baer (2002). One curious feature of the equal per-capita approach is the following: Singer (2002) argues largely on pragmatic grounds that such an approach to the division of the burdens of climate change would be appropriate, suggesting that this would let the industrialized countries off lightly, compared to ideas such as accountability for past emissions. As opposed to that, Frankel (2007) dismisses this idea as unrealistic, but he in turn is being criticized by other contributors to Aldy and Stavins (2007a) as making an unrealistic proposal, being a defender of a an international institutional framework within which emissions quotas are set. Appeals to pragmatism play interestingly different roles in these debates.
} 
might allocate payments to countries although such payments would be disconnected from any of these issues. ${ }^{28}$ Such effects would be innocuous if there were an ex-ante entitlement to an equal share of pollution. Alas, in the absence of such entitlements, these implications render the equal per-capita approach implausible. "[E]veryone has the same claim to part of the atmospheric sink, at least as a starting point for discussion,” says Singer (2002), p 35, “and perhaps, if no good reasons can be found for moving from it, as an end point as well.”29 But we have now articulated a good reason for moving from it.

7. So the equal per-capita approach is implausible. Let us look at the idea that past emissions ought to be taken into account when we regulate access to the absorptive capacity of the atmosphere, where for now I mean by "past emissions” emissions before 1990. (I occasionally talk about the principle of historical accountability, parallel to the principle of equal per-capita allocation.) The point of this approach is that, regardless of how we spell this out, the fact that now-industrialized nations have used up some of the absorptive capacity in the past should matter for what access they obtain now. Conceivably, even those emissions should matter that took place before human activities were tied to the greenhouse effect, or before the greenhouse effect was understood. ${ }^{30}$

\footnotetext{
${ }^{28}$ Singer (2002) addresses the concern that not every country might be able to put such payments to good use, or might have a government that should be trusted with them. He suggests a solution to that problem (a form of trusteeship). However, the objection formulated above is of a different nature.

${ }^{29}$ Neumayer (2000) captures a similar thought: “The natural absorptive capacity of the planet earth (...) truly belongs to nobody and should therefore be equally assigned to everybody in order to give everybody equal opportunity to benefit from emissions" (p 188).

${ }^{30}$ One version of the equal per-capita approach can be developed in terms of historical per-capita assignments, but one can take historical emissions into account without endorsing an equal per-capita approach. Historical accountability is also known under the name "natural debt", or "ecological debt;" see Gruebler and Fujii (1991), Smith (1991), Simms (2005), Neumayer (2000). The most recent decades have contributed disproportionately to climate change: According to the 2007 IPCC mitigation report, there was
} 
There has been a good deal of discussion of historical emissions. ${ }^{31}$ The following considerations support the view that past emissions should be disregarded: First, past emitters, at least in earlier stages of industrialization, did not know, and (in any relevant sense of "could") could not have known, the effects of greenhouse gas emissions. Nor could they have known that fossil fuels would remain essential to the economy for centuries to come: their emissions only became part of a problem because economies continued to depend on fossil fuels. One should also not forget that, as documented for example in Karl Polanyi's study on the Great Transformation and illustrated in Emile Zola's Germinal, the earlier stages of industrialization were traumatic for the lower social classes. Thinking of that age, one should not cherish an image of happy consumers.

Second, it is unclear who precisely caused what damage. Nor is it clear who should be held accountable: is it only states, or also companies or individuals? Such questions create difficulties for assigning responsibilities for past emissions. ${ }^{32}$ Third, many of the benefits of industrialization have spread across the world. Developing countries that wish to industrialize benefit from inventions that emerged from earlier industrialization efforts, which had to use inferior technology. ${ }^{33}$ Moreover, countries

a 70\% increase of greenhouse gas emissions between 1970 and 2004, 24\% between 1990 and 2004 (p 3). Marland et at. (2006) report that "[s]ince 1751 roughly 305 billion tons of carbon have been released to the atmosphere from the consumption of fossil fuels and cement production. Half of these emissions have occurred since the mid 1970s.”

${ }^{31}$ See Shue (1996), (1999), Gardiner (2004), Caney (2006), Grubb et al (1992), Gosseries (2004), Singer (2002).

${ }^{32}$ See Caney (2006) and (2008) for a discussion of these difficulties. Following Houghton (2004), p 150, he illustrates the difficulties of ascribing amounts of harm to climate change by pointing out that, for instance, the sea level in Bangladesh would have risen to a certain extent anyway, because of soil erosion.

${ }^{33}$ This should be kept in mind in reference to statements such as this in Neumayer (2000): “To ignore historical accountability would mean to privilege those who lived in the past in the developed countries and to discriminate against those who live in the present or will live in the future developing countries” (p 188). 
other than those where most emissions have occurred have benefited from those emissions via trade, as well as via the spread of technologies and scientific understanding whose development became possible only in industrialized societies.

I grant that the second point above fails: ${ }^{34}$ one cannot block demands for the integration of past emissions into future-directed regulation on the strength of difficulties in assigning responsibilities. There has been much controversy about the third point, that developing countries too have benefited from industrialization, and that therefore the economic changes of the last centuries have seen a global economic development that has benefited everybody. Shue (1999) responds that developing countries have paid for the benefits they have obtained. Singer (2002) points out that, at any rate in the US, most goods and services produced in the country (89\%, p 39) are geared towards domestic consumption. Yet life quality has improved across the world since the beginning of the industrial revolution, in terms of criteria such as income, longevity, child mortality, or literacy. These benefits are impossible to detach from industrialization and have indeed been of global reach, no matter how differentially they have taken effect. ${ }^{35}$ Still, not all past emissions can be accounted for in this way. Although it is also true that we should not think of at least the early stages of industrialization as happy days, a fair amount of past human activities that have contributed to climate change cannot be seen as essential contributions to changes that have benefited most people.

Crucial, then, is the first point above. If such emitters did no wrong in the first place, no further questions about integrating past emissions into future-directed

\footnotetext{
${ }^{34}$ Granting this makes my argument more difficult since I seek to rebut this principle of historical accountability, so I will not dwell on this point.

${ }^{35}$ For elaboration of this claim, see Risse (2005a), and (2005b).
} 
regulation arise. Past emissions could then not factor into such regulation. If early emitters did no wrong, it will be irrelevant that these emissions cannot all be regarded as necessary elements of an overall beneficial economic development, as well as that we have granted to the opponent that we can find a plausible current assignment of responsibilities for past emissions. Consider an objection to the relevance of this point. Tort law in some countries endorses strict liability, that is, accountability without fault or wrong-doing of any sort. Could this notion not allow us to hold people accountable for past emissions although nobody has ever committed a moral wrong, or been at fault for them occurring in the first place? Yet this is implausible. Strict liability has to overcome a presumption of unfairness. It should not be applied without the affected individuals being aware of its applicability. Only then could they make a choice whether to participate in the relevant activities. If they cannot make such a choice, it would be unfair to hold them accountable. Therefore, strict liability should not apply under conditions where, crucially, people did not have the required background understanding to act in certain ways. ${ }^{36}$

So did past emitters do any wrong? According to the standpoint of Common Ownership, in addition to areas that are subject to private appropriation, there are areas that should be left in common ownership, or else be governed by conventions that go beyond common ownership without allowing for appropriation by occupation. What the ownership status of these areas ought to be depends on the available technology, and might change over time. So the ownership status of these areas is conventional, alas not

\footnotetext{
${ }^{36}$ On strict liability, see Murphy and Coleman (1990), pp 126-130. I take strict liability to be opposed to both a fault-based principle and a principle that restricts liability to cases in which people would be accountable if they committed a moral wrong even though they might not be to blame for it. It in this strong version of that I am setting aside strict liability. The distinction between (blameworthy) faults and moral wrongs will matter below.
} 
in the manner in which, say, driving on the right side versus driving on the left side is. That choice is arbitrary, whereas the choice of conventions regulating access to certain parts of the earth is subject to criteria of reasonableness and appropriateness. Technological advancements have turned the absorptive capacity of the earth into a good in need of regulation. Yet at earlier stages of using certain technologies (those that increase greenhouse gas concentrations), it was not and (again, in any relevant sense of “could”) could not have been known that these technologies had this effect. Therefore, at that stage, people were not expected to adopt any regime of access to the absorptive capacity of the earth other than to leave this good unregulated. ${ }^{37}$

So does this mean, then, that early emitters did not do any wrong? On both Grotian accounts of the emergence of property regimes that go beyond the original ownership, changes in ownership status are reasonable adjustments to new circumstances. But now we arrive at a distinction between what people, objectively speaking, ought to have done by way of adopting new property conventions, and what they could reasonably have been expected to do. In moral theory this situation is familiar. We often appeal to what individuals had reason to do by way of assessing what they should be blamed, or could be excused, for. Yet we think of rightness and wrongness differently, in terms of what objectively speaking, or all things considered, ought to have been done. In light of this distinction, we cannot conclude that early emitters did no wrong. In hindsight, all things considered, the right course of action would have been to adopt conventions of access to the absorptive capacity that would have limited emissions. Put differently,

\footnotetext{
${ }^{37}$ We can remain non-committal with regard to the question of what such a "regime of access" actually might have amounted to. But the spectrum of possibilities is not limited to international treaties. Such a regime might amount to no more than the emergence of certain international practices.
} 
objectively speaking, technological abilities in the early stages of industrialization were already such that a new regime of access to that capacity was required.

Still, a set of conditions of maximally excusatory force applied to early emitters. The standpoint from which it is correct to say that decision makers in the past ought to have adopted different norms sets aside earlier scientific limitations. People could not have been expected to accept different conventions for the atmosphere at those early stages. They have compelling excuses for not having done so. "[A]ttempts to apply faultbased standards are virtually guaranteed to become embroiled in more or less irresolvable controversy about historical explanations," says Shue (1996), p 16. "Yet never to attempt to assess fault is to act as if the world began yesterday.” We can indeed assess fault, but there was no fault in the past. The world did not begin yesterday, but what was right and wrong with regard to the absorptive capacity, as well as what people could reasonably be expected to know about it, has changed over time. It was wrong of earlier emitters not to take precautions, but they cannot be blamed.

What is the relevant time such that past emitters should not be blamed for emissions before that stage? Gosseries (2005) mentions various dates that might matter, ${ }^{38}$ among them 1896 (the publication of an article by Arrhenius on the greenhouse effect, what Neumayer (2000) calls "the first warning of global warming” (p 188)); 1967 (the publication of the first serious modeling exercise on the matter); 1990, and 1995 (the publication of the first and second IPCC report). ${ }^{39}$ Neumayer (2000), a defender of

\footnotetext{
${ }^{38}$ See also Simms (2005), chapter 2, for the history of the discovery of climate change.

${ }^{39}$ Singer (1990) also discusses 1990 as a plausible year, but then indexes his own version of the equal percapita approach to the year 2050.
} 
historical accountability, thinks it would be unfair to say it was that the public and decision-makers became aware of the greenhouse effect before the mid 1980s. The UN Framework Convention on Climate Change in 1992 would also set a plausible date. The years of the publication of the third and fourth IPCC report (2001 and 2007), would be possible dates as well, as both reports contributed to more clarity on climate change.

As far as the assignment of blame is concerned, the decisive question is from when on decision makers could reasonably be expected to know about the dangers that might result from climate change and to take measures in response. Needless to say, picking any particular single year for that purpose is bound to be unsatisfactory. Yet with that limitation in mind, 1990 strikes me as the latest sensible date: after all, the 1990 IPCC report was already summing up a body of empirical insights that had been gathered over the years. At the same time, in light of the relevance to and visibility of the first IPCC report among policy makers, and in light of persistent doubts that there would otherwise remain about what actual decision makers might be expected to have thought about, 1990 also is a sensible choice of a date -- provided the actual proposal for the distribution of burdens from climate change acknowledges reasons other than rectification of blameworthy past emissions as reasons for which disadvantaged countries can demand support in dealing with climate change. In that case, the particular importance of 1990 can make us neglect the facts that it is the latest sensible choice of a date in this context, and that any choice of a particular date is bound to be unsatisfactory. (The proposal in the next section does acknowledge such additional reasons.) With some hesitation I adopt 1990 as the relevant date, which is why I have stipulated from the beginning on that past emissions are those made prior to 1990. 
My concern in arguing that past emitters cannot be blamed is not to absolve rich countries from responsibility when it comes to taking on the burdens of climate change. But my point below will be, instead, that they should shoulder those burdens primarily because they are rich, not because they have made past emissions. To clarify intuitions, suppose country X polluted heavily, but then fell into economic decline, following World War II, and never recovered. Since then their emissions have been considerably below those of earlier days. Should they be held accountable for past emissions? If one answers 'no,' one presumably does so guided by the idea that the rich should pay, rather than that past emitters should. Often those who are rich now are also past emitters, but we should nevertheless keep apart these two reasons. But again, while we have argued that past emitters before 1990 should not be blamed, we could not show that they did not do anything wrong. We will revisit this point below. The fact that past emitters did indeed do a moral wrong will have to enter any sensible proposal for the allocation of burdens somehow, even if we do not blame them.

8. How, then should we regulate access to the earth's absorptive capacity from now on? Recall the structure of our argument. We have established first that, according to the ownership standpoint, access to the absorptive capacity of the earth needs to be regulated. Such regulation is morally required for the exercise of natural common ownership rights. This move raised the question of how to regulate such access fairly. The standpoint of Common Ownership, that is, shows that distributive questions that arise about climate change form a moral problem of a particular character. We have explored two proposals for such regulation, the equal per-capita approach and the approach in terms of historical 
accountability. We have rejected the equal per-capita approach. We have now seen in addition that any plausible version of the principle of historical accountability cannot turn on the fact that past emitters are to be blamed for their emissions, nor (as we noticed in passing) can it be based on a strict-liability principle that disregards any concerns about blameworthiness and moral wrongdoing. These results may be surprising on both counts, and for rather different reasons. An equal-per-capita approach would strike many as the natural way of assigning burdens from climate change according to the standpoint of collective ownership, whereas the principle of historical accountability seems to have little to do with that standpoint in the first place.

The proposal for regulating access to the absorptive capacity of the earth that I am about to make gains plausibility from the negative aspects of these findings (i.e., the rejection of competing proposals), and at the same time will be sensitive to the fact that we have not been able to conclude the past emitters did not do any wrong (but merely that they could not be blamed for what they did). As I said before, it is common for debates about fair division problems that support for one among several prima facie plausible ideas comes from problems with other proposals-- thus in this case from the fact that we did not find an equal-per-capita approach plausible, and from the fact that we did not find a principle of historical accountability plausible that blames past emitters. Our goal now is to articulate plausible versions of a "polluter pays” principle and an "ability to pay principle,” one condition on their plausibility being that they integrate our findings on blameworthiness and moral wrongdoing of past emissions in a sensible manner. ${ }^{40}$

\footnotetext{
${ }^{40}$ By making this transition from the principles we have discussed before to plausible versions of the ability-to-pay and the polluter-pays principle I am setting aside other principles that are also sometimes discussed in the literature, such as: the willing pay; states or individuals ought to bear comparable burdens; respect for the status quo should be guiding; the land area should be decisive; broader distributional
} 
To set the stage, distinguish between burdens from adaptation and burdens from mitigation. (The beginning of this essay sketches these burdens.) We will consider these burdens separately because burdens from adaptation raise questions of rectificatory justice (that is, turn on backward-looking questions about culpability and wrong-doing for which compensation might be owed) whereas burdens from mitigation raise questions of distributive justice (that is, turn on forward-looking questions about how to assign sacrifices vis-à-vis projected business-as-usual trajectories from now on). This is not to say that the assignments of burdens are entirely independent of each other, but for analytical purposes it is useful to draw this distinction.

Among burdens from adaptation, in turn, we can distinguish burdens that arise because of emissions that occurred after people could be expected to regulate access to the absorptive capacity of the earth, and those that arise from emissions that occurred before that, and thus at a time before which individuals could be blamed for their emissions. This distinction will be impossible to draw practically without attracting considerable controversies, but our goal is to formulate ethical principles that should broadly guide the allocation of the burdens from global climate change in an envisaged set of treaties that would regulate allocations of emissions and possibly also financial transfers. Inevitably, the path from such principles to actual allocations of emissions and imposition of obligations of financial aid or penalties will be thorny, and will involve matters beyond the scope of our discussion (e.g., political and economic considerations that help determine how best to implement such emissions and transfers, in a manner that takes into account that such implementation is an intergenerational problem).

implications ought to be all that matters. I cannot argue this point here, but none of these proposals seems to have a comparable degree of plausibility as a moral approach than the proposals we are discussing. 
As far as burdens from both adaptation and mitigation are concerned, I assume that two general obligations apply. First, there is a generic obligation (located at the level of the global order) to help states realize human rights, and thus to help them create the conditions under which the realization of these rights is possible. Second, and related, there is a generic duty of assistance with building institutions. ${ }^{41}$ Climate change is one occasion on which these obligations apply. That is, one enormously sensible way of making good on these obligations is the sharing of technology to mitigate or adjust to climate change. It is because of the presence of these generic duties that the choice of the latest sensible date before which emissions are no longer blameworthy is not too worrisome. Stipulating that there are these particular obligations gives a shape to a more general duty of aid, one that is prima facie plausible enough and sufficiently present in the literature to be introduced here without argument. The details do not matter much, as long as the reader is willing to endorse some specifications of a general duty of aid. A reader unwilling to do so would have to reassess the choice of 1990 as the relevant date for determining for which emissions past polluters ought not be blamed. More would depend on that choice then. ${ }^{42}$

Consider now specifically burdens from adaptation. As a matter of rectificatory justice, countries that did not take considerable measures to reduce emissions after 1990, have a duty to compensate those that have been harmed because of this, with a priority on the poorer ones among them. To the extent that adaptation becomes necessary because of

\footnotetext{
${ }^{41}$ I have argued for these in Risse (2009a) and (2005c), respectively.

${ }^{42}$ Making sure that the choice of that particular date is not too worrisome is the only work done by this appeal to a general duty of aid here. We saw earlier that finding principles of fair access to the absorptive capacity of the earth is an implication of Common Ownership. So a reader who rejects the obligations stipulated above would thereby not reject the idea that the regulation of access to that capacity is itself morally required.
} 
emissions before 1990, no duty of rectificatory justice applies. As we saw, past polluters (i.e., those who emitted prior to 1990) cannot be blamed. They should therefore not be subject to duties of rectificatory justice regardless of their present wealth. We will see shortly, however - and I say this by way of responding to an obvious worry at this stage - that the fact that past polluters did after all commit a wrong enters this proposal as well.

Consider next burdens from mitigation. In this case, we are talking about burdens of distributive, rather than rectificatory, justice. Here, again, the main goal is to assess which countries need to make how much of a sacrifice, as compared to their projected business-as-usual trajectories. Most plausible - after we have rejected the equal percapita approach and the principle of historical accountability in a form that holds that past individuals are to be blamed - is that those should modify their production who, in terms of their per-capita wealth, are best able to afford the changes.

Moreover, for roughly equal levels of per-capita wealth levels, those countries should be expected to make more sacrifices that continue to benefit from emissions that occurred in the past. To the extent that we are talking about emissions before 1990, no blame would have to be assigned for these emissions. Nevertheless, gains from such emissions would be ill-gotten (and thus benefiting from them would amount to freeriding on ill-gotten gains), and the fact that such emissions continue to benefit countries should enter into the distribution at least in such a way that they differentiate among countries with roughly equal levels of wealth. It is in this manner that the fact that early polluter did something wrong although they cannot be blamed for it should enter into current allocations. At the same time, such countries would no longer be held accountable for their blameless but wrongful past emissions if they no longer benefit from them. In 
addition, again for roughly equal levels of per-capita wealth, those countries with unusually high per-capita emissions rates should be expected to make more sacrifices than countries with lower per-capita emission rates. For those countries could reasonably be expected to contribute more to the overall goal of reducing greenhouse gas concentrations. ${ }^{43}$ Overall, then, this proposal introduces an "ability to pay" principle, as well as a "polluters pays" principle that takes into account the result of our discussion of the principle of historical accountability.

The relevance of the "polluter-pays" components of this proposal (and their particular ways of being relevant) for the regulation of access to the earth's absorptive capacity should be sufficiently established and does not require additional arguments at this stage. In addition to the weaknesses of its competitor principles, the ability to pay principle is supported by two plausible principles stated succinctly by Shue (1999):

Among a number of parties, all of whom are bound to contribute to some common endeavor, the parties who have the most resources normally should contribute the most to the endeavor. (p 537)

When some people have less than enough for a decent life, other people have far more than enough, and the total resources available are so great that everyone could have at least enough without preventing some people from still retaining considerably more than others have, it is unfair not to guarantee everyone at least an adequate minimum. (p 541)

One might also stipulate a threshold of per-capita wealth below which countries should not be expected to do anything. There will be additional costs of adaptation that cannot be covered by the two categories of burdens from adaptation we already distinguished

\footnotetext{
${ }^{43}$ Michaelowski (2007) makes a proposal that combines per-capita wealth and per-capita emission, in such a way that the amount of sacrifices a country is expected to make is a function of both criteria. To this proposal I would like to add that past emissions ought to be integrated as proposed in the text. Gosseries (2005) argues that if one considers ignorance an excuse, one would in fact condone an unacceptable form of intergenerational free-riding. Baer (2006) too argues that there is something problematic about contemporary's benefiting from harmful activities in the past.
} 
above, namely, adaptation required because of emissions that occurred after an agreement was made. But we should think of an envisaged agreement concerning mitigation for which we have here suggested ethical principles as concerned with overall developments of economies, which includes measures of both adaptation and mitigation. ${ }^{44}$

More work needs to be done to add details to this proposal, as well as to think through what allocations of emissions and what other measures this proposal would entail. Still, the proposal we have sketched brings into reflective equilibrium the ethically relevant considerations for regulating access to the absorptive capacity of the atmosphere as they have emerged from our discussion of Common Ownership. Recall that the standpoint of Common Ownership also shows that distributive questions that arise about climate change form a moral problem of a particular character in the first place. That by itself should be an important contribution to the debate about the ethical dimensions of global climate change. Before the background of that contribution one could then also explore disagreement about the actual moral principles of regulation.

\section{Literature}

\footnotetext{
${ }^{44}$ Caney (2008) proposes a qualified version of the polluter pays principle where this holds that "persons should bear the burden of climate change that they have caused so long as doing so does not push them beneath a decent standard of living." However, he also argues that the polluter pays principle cannot cover all aspects of the problem (non-anthropogenic climate change, the emissions of the poor, and the emissions of past generations - what he calls "the Remainder"). This leads to a second principle, namely, that "the duties to bear the Remainder should be borne by the wealthy but we should distinguish between two groups -- (i) those whose wealth came about in unjust ways, and (ii) those whose wealth did not come about in unjust ways -- and we should apportion greater responsibility to (i) than to (ii).” This is quite similar to what I have proposed. By way of contrast: Panayotou et al. (2002) argue that each country should be expected to make sacrifices to the extent that it has contributed to the problem, and should be compensated to the extent that it suffers from the problem. So countries that contribute more to the problem than they suffer should be net-payers, and vice versa. They argue that the net-payers will be countries in temperate zones, and net-recipients countries in tropical zones.
} 
Agarwal, A, and S. Narain. 1991. Global Warming in an Unequal World. New Delhi: Center for Science and Environment

Aldy, Joseph, and Robert Stavins (eds.). 2007a. Architectures for Agreement. Addressing Global Climate Change in the Post-Kyoto World. Cambridge: Cambridge University Press

Aldy, Joseph, and Robert Stavins. 2007b. "Introduction: International Policy Architecture for Global Climate Change.” In Aldy and Stavins (2007a): pp 1-27

Aldy, Joseph, and Robert Stavins. 2007c. “Architectures for an International Global Climate Change Agreement: Lessons for the Policy Community.” In Aldy and Stavins (2007a), pp 350-367

Aldy, Joseph, Scott Barrett, and Robert Stavins. 2003. “Thirteen Plus One: Comparison of Global Climate Policy Architecture.” Climate Policy (3): pp 373-397

Athanasiou, Tom, and Paul Baer. 2002. Dead Heat: Global Justice and Global Warming. Seven Stories: New York

Baer, Paul. 2006. “Adaptation: Who Pays Whom?” In Neil Adger, Jouni Paavola, Saleemul Huq, and M. J. Mace (eds.), Fairness in Adaptation to Climate Change. Cambridge Massachusetts: MIT Press

Baer, Paul. 2002. "Equity, Greenhouse Gas Emissions, and Global Common Resources.” In S. Schneider, A. Rosencranz, and J. Niles (eds.), Climate Change Policy: A Survey. Washington D.C.: Island Press, pp 393-408

Becker, Lawrence. 1977. Property Rights: Philosophical Foundations. Boston: Routledge and Kegan Paul 
Beckerman, Wilfred. 1994. “'Sustainable Development’: Is it a Useful Concept?“ Environmental Values 3 (3): pp 191-209

Blake, Michael, and Mathias Risse. Forthcoming. "Immigration and Original Ownership of the Earth.” To appear in Notre Dame Journal of Law, Ethics, and Public Policy (special issue on immigration)

Blake, Michael, and Mathias Risse. 2007. "Migration, Territoriality, and Culture,” in New Waves in Applied Ethics, ed. J. Ryberg, T. Petersen, and C. Wolf, Ashgate Publishers

Brams, Steven, and Alan Taylor. 1996. Fair Division: From Cake Cutting to Dispute Resolution. Cambridge: Cambridge University Press

Bromley, David (ed.). 1992. Making the Commons Work. Theory, Practice, and Policy. San Francisco: Institute for Contemporary Studies

Broome. John. 1992. Counting the Cost of Global Warming. Cambridge: White Horse Press

Broome, John. 2003. "Discounting the Future.” Chapter 4 of Broome, Ethics out of Economics. Cambridge: Cambridge University Press

Buck, Susan. (1998). The Global Commons. An Introduction. Washington D.C.: Island Press

Buckle, Stephen. 1991. Natural Law and the Theory of Property. Grotius to Hume. Oxford: Clarendon

Caney, Simon. 2008. "Climate Change and the Duties of the Advantaged," forthcoming in Critical Review of International Social and Political Philosophy 
Caney, Simon. 2006. "Environmental Degradation, Reparations and the Moral Significance of History,” Journal of Social Philosophy, vol.73 no.3, pp.464-482

Cooney, Rosey, and Barney Dickson (eds.). 2003. Biodiversity and the Precautionary Principle. London: Earthscan

Cooper, Richard. 2007. “Alternatives to Kyoto: the Case for a Carbon Tax.” In Aldy and Stavins (2007a), pp 105-116

Cowen, Tyler, and Derek Parfit. 1992. “Against the Social Discount Rate.” In Peter Laslett and James S. Fishkin (eds.), Justice Between age Groups and Generations. New Haven: Yale University Press, pp. 144-161

Dubgaard, Alex. 2002. "Sustainability, Discounting, and the Precautionary Principle.” In Danish Ecological Council, Skeptical Questions and Sustainable Answers, pp 196-202. Copenhagen: Danish Ecological Council

Edmundson, William. 2004. An Introduction to Rights. Cambridge: Cambridge University Press

Foster, Kenneth, Paolo Vecchia, and Michael Repacholi. 2000. "Science and the Precautionary Principle.” Science Vol. 288, Issue 5468

Frankel, Jeffrey. 2007. “Formulas for Quantitative Emissions Targets.” In Aldy and Stavins (2007): pp 31-56

Gardiner, Stephen. 2004. "Ethics and Global Climate Change.” Ethics 114: pp $555-600$

Gardiner, Stephen. 2006. “A Core Precautionary Principle.” Journal of Political Philosophy 14: pp 33-60

Goodin, Robert. 1992. Green Political Theory. Cambridge: Polity Press 
Gollier, Christian. 2002. "Discounting an Uncertain Future.” Journal of Public Economics 85: pp 149-166

Gosseries, Axel. 2005. "Historical Emissions and Free Riding,” In Meyer (2004), pp 355-380

Goulder, Lawrence. 2003. "Benefit-Cost Analysis and Climate Policy.” In J. Griffin (ed.), Global Climate Change. Cheltenham: Edward Elgar, pp 6791

Grotius, Hugo. 2004. The Free Sea. Edited and with an Introduction by David Armitage. Liberty Fund: Indianapolis

Grotius, Hugo. 2005. The Rights of War and Peace. Edited with an Introduction by Richard Tuck. Liberty Fund: Indianapolis

Grotius, Hugo. 2006. Commentary on the Law of Prize and Booty. Edited and with an Introduction by Martine Julia van Ittersum. Liberty Fund: Indianapolis

Grubb, Michael. 1995. "Seeking Fair Weather: Ethics and the International Debate on Climate Change.” International Affairs 71: pp 463-496

Grubb, Michael, and James Sebenius, Antonio Magalhaes, and Susan Subak. 1992. "Sharing the Burden.” In: Irving Mintzer (ed.), Confronting Climate Change: Risks, Implications, and Responses. Cambridge: Cambridge University Press, pp 305-322 Gruebler, A, and Y. Fujii. 1991. "Intergenerational and Spatial Equity Issues of Carbon Accounts.” Energy 16, pp 1397-1416

Hanley, Nick, and Clive Spash. 1993. Cost-Benefit Analysis and the Environment. Aldershot: Elgar 
Harremoes, Poul, David Gee, Malcolm MacGarvin, Andy Stirling, Jane Keys, Brian Wynne, and Sofia Guedes Vaz. 2001. Late Lessons from Early Warnings: the Precautionary Principle 1896-2000. Luxembourg: European Environmental Agency

Hart, H. L. A. 1982. Essay on Bentham. Oxford: Oxford University Press

Honore, A. M. 1961. “Ownership.” In Making Law Bind: Essays Legal and Philosophical. Oxford: Clarendon

Hospers, John. 1971. Libertarianism. Los Angeles: Nash Publishing

Houghton, John. 2004. Global Warming: The Complete Briefing. Cambridge: Cambridge University Press

Hubin, Donald. 1994. "The Moral Justification of Benefit/Cost Analysis." Economics and Philosophy 10, pp 169-194

Hurka, Thomas. 1993. "Ethical Principles," Chapter 2 in Harold Coward and Thomas Hurka, Ethics and Climate Change: The Greenhouse Effect. Calgary: Calgary Institute for the Humanities

Intergovernmental Panel on Climate Change (IPCC). 2007a. Climate Change 2007: The Physical Science Basis. Contribution of Working Group III to the Fourth Assessment Report of the IPCC. Cambridge: Cambridge University Press

Intergovernmental Panel on Climate Change (IPCC). 2007b. Impacts, Adaptation, and Vulnerability. Contribution of Working Group II to the Fourth Assessment Report of the IPCC. Cambridge: Cambridge University Press

Intergovernmental Panel on Climate Change (IPCC). 2007c. Mitigation of Climate Change. Contribution of Working Group III to the Fourth Assessment Report of the IPCC. Cambridge: Cambridge University Press 
Jamieson, Dale. 2001. “Climate Change and Global Environmental Justice.” In P. Edwards and C. Miller (eds.), Changing the Atmosphere: Expert Knowledge and Global Environmental Governance. Cambridge: MIT Press

Jones, Peter. 1994. Rights. London: Macmillan

Kelman, Steven. 1981. “Cost-Benefit Analysis: An Ethical Critique.” AEI Journal on Government and Society Regulation (Jan/Feb. 1981), pp 33-40

Lee, Keekok, Alan Holland, and Desmond McNeill. 2000. Global Sustainable Development in the Twenty-First Century. Edinburgh: Edinburgh University Press

Lomborg, Bjorn. 2001. "Global Warming." In Lomborg, The Skeptical Environmentalist, pp 258-324. Cambridge: Cambridge University Press

Lomborg, Bjorn (ed.). 2004. Global Crises, Global Solutions. Cambridge: Cambridge University Press

Malanczuk, Peter. 1997. Akehurst’s Modern Introduction to International Law. Seventh Edition. London: Routledge

Marland, G., and T.A. Boden, and R. J. Andres. 2006. “Global, Regional, and National $\mathrm{CO}_{2}$ Emissions," in Trends: A Compendium of Data on Global Change (Carbon Dioxide Information Analysis Center, Oak Ridge National Laboratory, U.S. Department of Energy, Oak Ridge. This can be found at: http://cdiac.ornl.gov/trends/emis/tre_glob.htm

Meyer, Lukas. 2005. Justice in Time: Responding to Historical Injustice. BadenBaden: Nomos

Michaelowa, Axel. 2007. "Graduation and Deepening." In Aldy and Stavins (2007a), pp 81-105 
Miller, David. 2001. “Distributing Responsibilities.” Journal of Political Philosophy 9, pp 453-471

Murphy, Jeffrie, and Jules Coleman. 1990. Philosophy of Law: An Introduction to Jurisprudence. Boulder: Westview

Neumayer, Eric. 2000. “In Defense of Historical Accountability for Greenhouse Gas Emissions.” Ecological Economics 33, pp 185-192

Neumayer, Eric. 2003. Weak Versus Strong Sustainability: Exploring the Limits of Two Opposing Paradigms. Cheltenham: Elgar

Ostrom, Elinor. 1990. Governing the Commons. The Evolution of Institutions for Collective Action. Cambridge: Cambridge University Press

Page, Edward. 2006. Climate Change, Justice, and Future Generations. Cheltenham: Edward Elgar

Panayotou, Theodore, Jeffrey Sachs, and Alix Zwane. 2002. “Compensation for 'Meaningful Participation’ in Climate Change Control: A Modest Proposal and Empirical Analysis.” Journal of Environmental Economics and Management 43, pp 437-454

Pearce, David, Giles Atkinson, and Susana Mouratu. 2006. Cost-Benefit Analysis and the Environment: Recent Developments. Paris: OECD

Portney, Paul, and John Weyant (eds.). 1999. Discounting and Intergenerational Equity. Washington D.C.: Resources for the Future

Posner, Eric, and Cass Sunstein. 2007. “Climate Change Justice.” John M. Olin Law and Economics Working Paper No. 354, University of Chicago

Reeve, Andrew. 1986. Property. Atlantic Highlands: Humanities Press 
Risse, Mathias. 2004. “Arguing for Majority Rule.” The Journal of Political Philosophy (12:1), pp 41-64

Risse, Mathias. 2005a. "How Does the Global Order Harm the Poor?," Philosophy and Public Affairs, Vol. 33, No. 4, pp 349-376

Risse, Mathias. 2005b. "Do We Owe the Poor Assistance or Rectification?," Ethics and International Affairs, Vol. 19, No. 1, pp 9-18

Risse, Mathias. 2005c. "What We Owe to the Global Poor," The Journal of Ethics, Vol. 9, No. 1-2, pp 81-117

Risse, Mathias. 2009a. "Common Ownership of the Earth as a Non-Parochial Standpoint: A Contingent Derivation of Human Rights," forthcoming in European Journal of Philosophy

Risse, Mathias. 2009b. “A Right to Work? A Right to Leisure? Labor Rights as Human Rights," forthcoming in Journal of Law and Ethics of Human Rights

Rothbard, Murray. 1996. For a New Liberty. The Libertarian Manifesto. San Francisco: Fox and Wilkes

Ryan, Alan. 1987. Property. Milton Keynes: Open University Press

Sagoff, Mark. 1988. The Economy of the Earth. Philosophy, Law, and the Environment. Cambridge: Cambridge University Press

Sands, Philippe. 2003. Principles of International Environmental Law. Cambridge: Cambridge University Press

Schmalensee, Richard. 1998. "Greenhouse Policy Architectures and Institutions.” In William Nordhaus (ed.), Economics and Policy Issues in Climate Change.’Washington D.C.: Resources for the Future Press, pp 137-158 
Schmidtz, David. 2001. “A Place for Cost-Benefit Analysis.” Philosophical Issues 11, pp 148-171

Shue, Henry. 1996.”Environmental Change and the Varieties of Justice.” In Fen Osler Hamilton and Judith Reppy, Earthly Goods. Environmental Change and Social Justice. Ithaca: Cornell University Press, pp 9-29

Shue, Henry. 1999. "Global Environment and International Inequality." International Affairs 75 (3), pp 531-545

Shue, Henry. 2001. “Climate." In D. Jamieson (ed.), A Companion to Environmental Philosophy. Oxford: Blackwell, pp 449-459

Sidgwick, Henry. 2005. The Elements of Politics. London: Elibron Classics

Singer, Peter. 2002. “One Atmosphere.” Chapter 2 of One World: The Ethics of Globalization. New Haven: Yale University Press

Simms, Andrew. 2005. Ecological Debt. The Health of the Planet and the Wealth of Nations. London: Pluto Press

Smith, K. 1991. “Allocating Responsibility for global Warming: the Natural Debt Index.” Ambio 20, pp 95-96

Stavins, Robert (ed.). 2000. Economics of the Environment: Selected Readings. New York: Norton

Steiner, Hillel. 1994. An Essay on Rights. Oxford: Blackwell

Stokey, Edith, and Richard Zeckhauser. 1978. A Primer for Policy Analysis. New York: Norton

Summers, Lawrence. 2007. "Foreword.” In Aldy and Stavins (2007a), pp xviiixxvii 
Sunstein, Cass. 2002. Risk and Reason: Safety, Law, and the Environment. Cambridge: Cambridge University Press

Traxler, Martino. 2002. "Fair Chore Division for Climate Change.” Social Theory and Practice 28: pp 101-134

Tuck, Richard. 1999. The Rights of War and Peace. Oxford: Oxford University Press

Vallentyne, Peter, and Hillel Steiner (eds.). 2000a. The Origins of LeftLibertarianism: An Anthology of Historical Writings. New York: Palgrave

Vallentyne, Peter, and Hillel Steiner (eds.) 2000b. Left-Libertarianism and Its Critics: The Contemporary Debate. New York: Palgrave

Viscusi, W.K. 2004. "The Value of Life: Estimates with Risks by Occupation and Industry.” Economic Inquiry 42: pp 29-48

Viscusi, W. K., and J. Aldy. 2003. "The Value of Statistical Life: A Critical Review of Market Estimates Throughout the World.” Journal of Risk and Uncertainty 27: pp 5-76

Weitzman, Martin. 1998. "Why the Far Distant Future Should be Discounted at Its Lowest Possible Rate.” Journal of Environmental Economics and Management (36): pp 201-208

Wenar. Leif. 2005. "The Nature of Rights.” Philosophy and Public Affairs (33): pp 223-253

Young, Peyton. 1995. Equity. Princeton: Princeton University Press 